\title{
THE ROLE OF INFORMATION SOCIETY IN THE DEVELOPMENT OF FARHANGIAN UNIVERSITY
}

\author{
Amir Soltaninejad \\ $\mathrm{PhD}$ in Sociology, Invited lecturer of Farhangiyan University \\ amirsoltan59@gmail.com \\ Muhammad Ali Yaghoubi Poour \\ Bachelor of Educational Sciences, at Farhangian Nasir al-Din Tusi Kerman University \\ Ali Sadei \\ Faculty member of The Department of Human Science, Farhangiyan University, Tehran, Iran \\ alisadee81@yahoo.com \\ Majid Saadatzadeh \\ $\mathrm{PhD}$ in Sociology, Lecturer OF University of Applied Sciences \\ Masoumehossadat Mirzadi Gohari \\ M.A of Anthropology
}

\begin{abstract}
In this study, we attempted to examine the role of information society in the development of Farhangian University. The research method is descriptive-survey. The population of this study, being 145 peoplewas consisted of experts, staff and faculty members of Farhangian University of Kerman -in the academic year of 2014-2015. Access was possible to all members of the community and a list of available people was made. Using census methods, 145 people were selected as samples of the study among the staff and faculty members of Farhangian University. A research made questionnaire, having an optimal reliability and validity $(\alpha=0.88)$, was used in the study. Since the aim of this study was to evaluate the impact of the information society on the development of Farhangian University, a five-component scale was implemented; planning, organization, command, coordination and control. To test the hypotheses (rejection or acceptance) one- sample t test was used. The results indicated that experts, professors and staff of Farhangian University of Kerman believed that the role of the information society in the development of the university is at an average level in terms of planning and organizing; however, in terms of command, coordination and control, the role of the information society was lower than expected.
\end{abstract}

Keywords: information society, Farhangian University, planning, organization, command

\section{INTRODUCTION}

With a glance at the history of human civilization, we can realize that the most ancient records and documentation belonged to Sumerians who carved their massages on stones. The eighteenth century was a turning point in the history of documentation and an important era in Science, Technology and knowledge. The main focus of human attention in the industrial revolution, was on the technology. The connection of science, technology and the special needs to use the latest scientific achievements, created a new knowledge called Information Society (Ghaffari, 2003: 90).

Information society is the knowledge of information, features dominating the flow of information and the tools that prepare and maximize the access to information. The preparation includes a detailed scientific 
and documentary breakdown of information, collecting, organizing, storing, retrieving, interpreting, spreading and using of it (Burchinal, 2001).

Indiscriminate and massive increase of information, from 1970 onwards, led to the complex data organization and recording. So the use and access to the information became more difficult, but the development of digital technologies, the production of supercomputers, their speed of information processing, as well as their high capacity solved the problems. Thus, science, computing, storage, retrieval of information and human knowledge united and information society was created. Then, gradually the information society was combined with the concept of communication; by visiting one of the many databases, users were able to access a vast amount of information within just a few seconds. Since the combination of technologies, strategies, information and communication with the issue of technology, another branch of human science or skill was emerged called information society and communication technology (Dawn, 2003). Information society is turned into a powerful force in social, economic and political changes of the world. Many countries and regions of the world are not able to succeed in the development without adhering to the era of information. The potential effects of the information society on countries having digital gaps (the gap between the countries having digital information and those not having this knowledge) is getting more serious (Darliag, 2007). The increased use of information and communication society, results in the rapid expansion of information, in other words, the approaches in the development of the information society, has caused the universities to use the information society (Winglin, 2004).

Generally it can be argued that information society is created to generate effective distant communication, access to information and prevent accumulation and monopolization of information; nowadays the exchange of information in the world is done within a second. Therefore, to prevent backwardness, the educational and training managers need to use the information society, in order to develop and progress (Golmohammadi, 2002: 90).

Currently, many of the efforts made in the field of information society in the public sector, is faced with failure; Because the generation of thought and creativity, creation of harmonious and novel changes require special capabilities in the area of training and information society. The use of guidelines for the employment of information society at Farhangian University needs planning, organization, command, coordination and control (Mertous, 2006).

The educational system requires the management of different educational systems in the area of information society developments; however, Farhangian University (as one of the educational systems) is faced with great responsibility in the issue of education, also formal and informal tasks are handled by this university. Thus, it is realized that this organization plays a key role in advancement of science, management and education. In this regard, the increase in the ability of the educational system and the development and progress of society is very important (Jackson, 2000). Researches show that the educational systems which use the information society in the process of learning and education are more successful. Officials and those involved in educational system who dominate the learning environment can benefit from the information society in curriculum designing and teaching methods (Moses, 2002). Given the objective of this research -the role of information society on the development of the Farhangian University- and emphasizing the impact of the information society on education systems, we realize that the use of this technology results in the training guides for the development of Farhangian University (whose goal is to provide excellent training services). Thus it is necessary to provide facilities for the use of information society, otherwise the survival of the organization will face serious threats.

\section{METHOD}

This research is a descriptive survey study and given that descriptive studies, consider attitudes and viewpoints, the researchers have used the assumptions of descriptive studies to survey the samples. In the 
current study the survey method is used as the most appropriate design to examine the experts of Farhangian University.

\section{THE POPULATION, SAMPLING}

The population of this study, being 145 people- was consisted of experts, staff and faculty members of Farhangian University of Kerman -in the academic year of 2014-2015. Access was possible to all members of the community and a list of available people was made, so the population is finite. Using census methods, 145 people were selected as samples of the study among staff and faculty members of Farhangian University.

\section{THE INSTRUMENTS OF THE STUDY}

A research made questionnaire was used in the study to evaluate the impact of the information society on the development of Farhangian University of Kerman. The questionnaire consisted of 30 questions measured by the Likert scale (very high, high, medium, low and very low), and consists of 5 sub-scale; planning, organization, command, coordination and control. The validity was obtained by a pilot study of 30 samples (experts, staff and faculty members) and the use of Cronbach alpha 0.87 ; also in the final run the amount of Cronbach alpha was 0.88 which indicated the high validity of the study. Finally, the one sample $t$ was used compare experimental and theoretical average $(18=\mu)$.

Findings

In this section we have tested the questions and objectives study and offered the related tables obtained by t- test:

1. What is the role of information society in the development of Farhangian University?

Table1. The role of information society in the development of Farhangian University

\begin{tabular}{|l|l|l|l|l}
\hline Theoretical mean & Experimental mean & $\mathrm{t}$ & Degree of freedom & Significance level \\
\hline 18 & 17.80 & $01 / 2$ & 144 & 0.037 \\
\hline
\end{tabular}

According to the $t$, there is a significant difference $\alpha=0.05$ between the experimental mean the theoretical mean. Since the experimental mean is lower than the theoretical mean, so, based on the samples, the role of information society on the development of Farhangian University was below the average.

2. What is the role of information society in the planning of Farhangian University?

Table2. The role of information society in the planning of Farhangian University

\begin{tabular}{|l|l|l|l|l|l|l}
\hline Number & Item & $\begin{array}{l}\text { Theoretical } \\
\text { mean }\end{array}$ & $\begin{array}{l}\text { experimental } \\
\text { mean }\end{array}$ & $\mathrm{t}$ & $\begin{array}{l}\text { Degree of } \\
\text { freedom }\end{array}$ & $\begin{array}{l}\text { Significance } \\
\text { level }\end{array}$ \\
\hline 1 & $\begin{array}{l}\text { Identification and } \\
\text { development academic } \\
\text { goals }\end{array}$ & 18 & $75 / 17$ & - & 144 & 0.040 \\
\hline 2 & $\begin{array}{l}\text { Identification and } \\
\text { development of curricula }\end{array}$ & 18 & $16 / 18$ & 1.34 & 144 & 0.071 \\
\hline 3 & $\begin{array}{l}\text { Appropriateness and the } \\
\text { adaptation of } \\
\text { objectives of curriculum } \\
\text { and syllabus }\end{array}$ & $02 / 18$ & 0.23 & 144 & 0.089 \\
\hline
\end{tabular}




\begin{tabular}{|l|l|l|l|l|l|l}
\hline 4 & $\begin{array}{l}\text { Application of Principles } \\
\text { and Techniques }\end{array}$ & 18 & $65 / 17$ & - & 144 & 0.090 \\
\hline 5 & $\begin{array}{l}\text { Facilitation and } \\
\text { development of the course } \\
\text { plan }\end{array}$ & 18 & $83 / 17$ & - & 0.71 & 144 \\
\hline 6 & $\begin{array}{l}\text { Appropriate use of models } \\
\text { of teaching - learning }\end{array}$ & 18 & $97 / 18$ & 3.50 & 144 & 0.375 \\
\hline total & planning & 18 & $64 / 18$ & - & 144 & 0.214 \\
\hline
\end{tabular}

According to the t, there isn't a significant difference $\alpha=0.05$ between the experimental mean the theoretical mean. Since the experimental mean and the theoretical mean are equal, the role of information society on the development of Farhangian University was average in the dimension of Planning.

3. What is the role of information society in the organization of Farhangian University?

Table3. The role of information society in the organization of Farhangian University

\begin{tabular}{|c|c|c|c|c|c|c|}
\hline Number & Item & $\begin{array}{l}\text { Theoretical } \\
\text { mean }\end{array}$ & $\begin{array}{l}\text { experimental } \\
\text { mean }\end{array}$ & $\mathrm{t}$ & $\begin{array}{l}\text { Degree of } \\
\text { freedom }\end{array}$ & $\begin{array}{l}\text { Significance } \\
\text { level }\end{array}$ \\
\hline 7 & Reduction of labor costs & 18 & 18.09 & 0.71 & 144 & 0.0475 \\
\hline 8 & $\begin{array}{l}\text { Reduction of the cost of } \\
\text { consumables such as } \\
\text { paper }\end{array}$ & 18 & 18.28 & 2.10 & 144 & 0.037 \\
\hline 9 & $\begin{array}{l}\text { Reduce the cost of } \\
\text { Educational Equipment }\end{array}$ & 18 & 18.84 & 2.74 & 144 & 0.007 \\
\hline 10 & Efficient use of space & 18 & 18.08 & 0.69 & 144 & 0.486 \\
\hline 11 & $\begin{array}{l}\text { Efficient use of } \\
\text { educational calendar }\end{array}$ & 18 & 18.24 & 2.01 & 144 & 0.048 \\
\hline 12 & $\begin{array}{l}\begin{array}{l}\text { Acceleration in the } \\
\text { recruitment } \\
\text { specialists }\end{array} \\
\text { of }\end{array}$ & 18 & 17.83 & $\overline{-}-27$ & 144 & 0.205 \\
\hline total & Organizing & 18 & $05 / 18$ & 0.78 & 144 & 0.435 \\
\hline
\end{tabular}

According to the $t$, there isn't a significant difference $\alpha=0.05$ between the experimental mean the theoretical mean. Since the experimental mean and the theoretical mean are equal, the role of information society on the development of Farhangian University was average in the dimension of organization.

4. What is the role of information society in the commanding of Farhangian University?

Table4. The role of information society in the commanding of Farhangian University

\begin{tabular}{|l|l|l|l|l|lr|l}
\hline Number & Item & $\begin{array}{l}\text { Theoretical } \\
\text { mean }\end{array}$ & experimental mean & $\mathrm{t}$ & $\begin{array}{l}\text { Degree } \\
\text { freedom }\end{array}$ & $\begin{array}{l}\text { Significance } \\
\text { level }\end{array}$ \\
\hline
\end{tabular}




\begin{tabular}{|c|c|c|c|c|c|}
\hline 13 & 18 & 17.17 & 1.25 & 144 & 0.271 \\
\hline 14 & 18 & 16.69 & $\overline{\bar{l}} \overline{0.30}$ & 144 & 0.563 \\
\hline 15 & 18 & 16.24 & $\overline{-}$ & 144 & 0.054 \\
\hline 16 & 18 & 17.37 & $\overline{-}-60$ & 144 & 0.001 \\
\hline 17 & 18 & 16.60 & $\overline{-}-\bar{l}$ & 144 & 0.002 \\
\hline 18 & 18 & 17.83 & $\begin{array}{l}- \\
.27\end{array}$ & 144 & 0.205 \\
\hline total & 18 & 17.80 & $\overline{-}$ & 144 & 0.063 \\
\hline
\end{tabular}

According to the $t$, there isn't a significant difference $\alpha=0.05$ between the experimental mean the theoretical mean. Since the experimental mean and the theoretical mean are equal, the role of information society on the development of Farhangian University was below the average in the dimension of commanding.

5. What is the role of information society in the coordination of Farhangian University?

Table5. The role of information society in the coordination of Farhangian University

\begin{tabular}{|l|l|l|l|l|l|l}
\hline Number & Item & $\begin{array}{l}\text { Theoretical } \\
\text { mean }\end{array}$ & $\begin{array}{l}\text { experimental } \\
\text { mean }\end{array}$ & $\mathrm{t}$ & $\begin{array}{l}\text { Degree of } \\
\text { freedom }\end{array}$ & $\begin{array}{l}\text { Significance } \\
\text { level }\end{array}$ \\
\hline 19 & $\begin{array}{l}\text { Adaptation of individuals } \\
\text { with organizational goals }\end{array}$ & 18 & 16.99 & 0.01 & 101 & 0.999 \\
\hline 20 & $\begin{array}{l}\text { Identification of long-term } \\
\text { goals }\end{array}$ & 18 & 15.70 & 2.27 & 144 & 0.035 \\
\hline 21 & $\begin{array}{l}\text { Facilitating the creation of } \\
\text { strategic management }\end{array}$ & 18 & 17.65 & - & 144 & 0.021 \\
\hline 22 & $\begin{array}{l}\text { Increasing unity between } \\
\text { the human resources }\end{array}$ & 18 & 16.48 & - & 144 & 0.041 \\
\hline $\begin{array}{l}\text { purpose orientated human } \\
\text { resources activities }\end{array}$ & 18 & 17.70 & - & 144 & 0.005 \\
\hline
\end{tabular}




\begin{tabular}{|l|l|l|l|l|l|l}
\hline 24 & $\begin{array}{l}\text { Reduction of } \\
\text { contradictions between the } \\
\text { personal goals and } \\
\text { objectives }\end{array}$ & 18 & 17.88 & - & 144 & 0.280 \\
\hline total & Coordination & 18 & 17.71 & - & 144 & 0.003 \\
\hline
\end{tabular}

According to the $t$, there is a significant difference $\alpha=0.05$ between the experimental mean the theoretical mean. Since the experimental mean is lower than the theoretical mean the role of information society on the development of Farhangian University was below the average in the coordination dimension.

6. What is the role of information society in the control of Farhangian University?

Table6. The role of information society in the control of Farhangian University

\begin{tabular}{|c|c|c|c|c|c|c|}
\hline Number & Item & $\begin{array}{l}\text { Theoretical } \\
\text { mean }\end{array}$ & $\begin{array}{l}\text { experimental } \\
\text { mean }\end{array}$ & $\mathrm{t}$ & $\begin{array}{l}\text { Degree } \\
\text { of } \\
\text { freedom }\end{array}$ & $\begin{array}{l}\text { Significance } \\
\text { level }\end{array}$ \\
\hline 25 & $\begin{array}{l}\text { Identification of } \\
\text { the organizational } \\
\text { performance }\end{array}$ & 18 & 18.73 & -2.10 & 144 & 0.037 \\
\hline 26 & $\begin{array}{l}\text { Identification of } \\
\text { the teachers }\end{array}$ & 18 & 18.36 & 3.52 & 144 & 0.001 \\
\hline 27 & $\begin{array}{l}\text { Identification the } \\
\text { executives }\end{array}$ & 18 & 18.31 & 2.84 & 144 & 0.005 \\
\hline 28 & $\begin{array}{l}\text { Clarity in job } \\
\text { description }\end{array}$ & 18 & 18.36 & 3.23 & 144 & 0.002 \\
\hline 29 & $\begin{array}{l}\text { Compilation of } \\
\text { organizational } \\
\text { chart, Gantt chart }\end{array}$ & 18 & 18.33 & 3.02 & 144 & 0.003 \\
\hline 30 & $\begin{array}{l}\text { Direct and indirect } \\
\text { supervision on } \\
\text { students' learning }\end{array}$ & 18 & 18.22 & 1.63 & 144 & 0.105 \\
\hline total & control & 18 & 18.45 & 2.46 & 144 & 0.015 \\
\hline
\end{tabular}

According to the $t$, there is a significant difference $\alpha=0.05$ between the experimental mean the theoretical mean. Since the experimental mean is higher than the theoretical mean the role of information society on the development of Farhangian University was higher than the average in the control dimension.

\section{DISCUSSION AND CONCLUSION}


Present era is a combination of communication and information. An era in which human beings need knowledge and communication more than ever. Nowadays, with the possession of advanced information and communication technologies, the rapid establishment of communication and exchange of information has been possible. People can get the latest information wherever they are. But undoubtedly, the greatest impact on learning environments has been the emergence of information and communication technologies. The use of information and communication technology in education has led to the virtual learning environment. This causes the communication of people in the form of teaching and spreading of knowledge be possible through computers. The present study investigated the role of information society in the development of Farhangian University. One sample $t$ test was used to investigate that role from the viewpoints of experts, staff, and faculty members. The results showed that the role of information society in the development of Farhangian University in the dimensions of organization and planning was at an average level, this is consistent with the results of the investigations of Shabani (2003) and Ghafari (2004); they investigated the role of information technology in the development of the educational system. But the role of information society in terms of command, coordination and control is lower than the average. Due to the low indicators of the Information Society at the University of Farhangian, it is recommended that officials and managers take advantage of information society indicators in education, research and patterns of teaching and learning to finally reach the concept of culture building in the society.

\section{REFERENCES}

Golmohammadi, Ahmad, (2002), globalization and cultural identity, Ney publication Shabani, M. (2003) Principles of program development and application of ICT on empowerment educational system Ghafari, Akbar, (2010) The Influence of IT on the improve government of management, Educational Technology Quarterly, Issue 7

Burchinal, L.G., Martinic, L., \& Wolff, L. (2001). Using technology to manage education information. ERIC and REDUC. Retrievedfrom www.TechKnowLogia.org

Darliag, D., \& Mclanghlin, R. (2007). ICT, novel educational and empowerment. The Journal of Mangement, 60 (20), 12-18.

Dawn, R. (2003). Development crisis and altemative vision: Third world women's perspectives. Bergen: Christian Michelsen Institute.

Jackson, G. B. (2000). How to evaluate educational software and websites. Retrieved from www.TechKnowLogia.org

Jackson, G. B. (2001). Evaluating Computer and Web Instruction: New opportunities. Retrieved from www.TechKnowLogia.org

Kozma, R. (2006). The study use ration of ICT. The Journal of Mangement, 42 (3), 30-32.

Means, B., \& Olson, H. (2005). The use ratio of ICT in the American schools. The Journal of Mc Growhill, 20(2), 15-18.

Mertous, A. (2006). Teachers and machines: The classroom use of technology since 1920. New York: Teachers College Press.

Moses, K. (2002). Educational system computer maintenance and support: They cost more than think! Retrieved from www.TechKnowLogia.org

Winglin, A. (2004). The ICT effect on the empowerment in England students. The Journal of Psycho Social, 12(21), 22-25 